\title{
Cointegration Between Macroeconomic Variables and Sectoral Indices Movement in Bursa Malaysia
}

\author{
Jaafar Pyeman (Corresponding Author) \\ Faculty of Business \& Management \\ Universiti Teknologi MARA, 42300, Bandar Puncak Alam, \\ Selangor Darul Ehsan, Malaysia \\ Tel: +6016-2206114 E-mail:jaaf@salam.uitm.edu,my \\ Ismail Ahmad \\ Faculty of Business \& Management \\ Universiti Teknologi MARA, 42300, Bandar Puncak Alam, \\ Selangor Darul Ehsan, Malaysia \\ Tel: +603-32587045 E-mail:drismailahmad@salam.uitm.edu,my
}

\begin{abstract}
This paper examines the cointegration between sectoral indices in Bursa Malaysia and the selected macroeconomic variables, namely, oil price (OP), gold price (GP), and exchange rate (ER), during the period 19952014. The underlying series are tested by using Unit Root Test, Johansen Cointegration, Vector Error Correction Model (VECM) and Vector Autoregression (VAR). The results indicate that sectoral indices, specifically in technology sector, have long run cointegration with macroeconomic variable as resulted from the analysis of Johansen-Juselius (1990), Multivariate Cointegration and Vector Error Correction Model. Meanwhile, the short run cointegration between macroeconomic variable and several sectoral indices have also been observed in Bursa Malaysia.
\end{abstract}

Keywords: Vector Error Correction Model;Vector Autoregression Model; Macroeconomic Variable; Sectoral Indices

\section{Introduction}

The Malaysian stock market, also known as Bursa Malaysia, is one of the biggest stock markets in Southeast Asia, and it plays a very important role in developing Malaysia's investment market. Formerly known as Kuala
Lumpur Stock Exchange (KLSE), Bursa Malaysia is an exchange holding company and is currently one of the largest bourses in ASEAN. There are 10 main indices at Bursa Malaysia, namely, Construction, Consumer Product, Industrial Production, Trading/Services, Technology, Finance, Properties, Plantation, Mining and Industrial. As a stock market, Bursa Malaysia was also globally affected due to the several crises such as financial crisis that happened in year 2007 and 2008, debt crisis in Greece, credit crisis and China's market crash. However, there was a main concern regarding this financial crisis issue, which is, the volatility of the stock market changes. Understanding the volatility of stock market is deemed crucial to determine the cost of capital and to assess investment and leverage decisions as volatility is perceived as a risk. Hence, stock market has become an important tool in developing and sustaining capital formation and economic growth in Malaysia. It has become essential for stock markets in Malaysia to nurture capital and sustain the economic growth. The estimation of differences in aggregate sectoral indices changes can be attributed by many categories of economic views. To begin with, there are many interconnected factors such as economic, political and psychological that affects stock market; however, if stock market is increasing, foreign capital can also be attracted. When there is a decline in stock prices, the country and 
corporate's wealth will lessen due to the decline. When the stock prices drops, the currency will also depreciate. Thus, it would be great to examine the changes in Malaysia's stock market with some macroeconomic variables.

Several studies in Malaysia as well as other countries have been conducted on the cointegration between macroeconomic variable with stock market (Kpanie, Esumanba and Sare, 2014; Joshi and Giri, 2013; Rahman, Sidek and Tafri, 2009). However, there are minimal studies performed by researchers about the cointegration of sectoral indices from macroeconomic variables perspective as mentioned by Rahman, Sidek and Tafri (2009) and Jaafar and Ismail (2009). As a developing country, Malaysia has a lot to offer in terms of its ever-changing macroeconomic variables. Understanding the cointegration between the selected variables (crude oil price, gold price and exchange rate) is important in this analysis. This is because as developing economies like Malaysia continue to grow and prosper, it will exert a larger influence on the global economy. Mohamed, Ali, Abdullah and Azman (2011) concured that the dramatic changes in all sectors of Bursa Malaysia were due to the globalization and liberalization concepts that are being applied by the Malaysian government. They also mentioned that the performance of companies listed in the Main Market fluctuated based on the market condition and has affected several factors such as economic, financial, business and liquidity.

\section{Cointegration between Stock Market Movement and Selected Macroeconomic Variables (Gold Price, Oil Price and Exchange Rate)}

Gold has been a part of economic life in many cultures and generations. As an asset, it tends to be particularly attractive during period of economic uncertainty or politically instability. A study by Sujit and Kumar (2011) who examined the cointegration between gold price, oil price, exchange rate and sectoral indices came with a conclusion that volatility in exchange rate is derived from other three variables. The study finds that gold price fluctuations depend on the commodity itself, not from oil price or other indexes. Due to unstable world markets, there is an increasing interest in gold. Some financial theories argue that gold could be considered as a safe investment when the economic environment is uncertain. When other investments are decreasing, gold usually increases. Gold is mostly considered as independent of other factors, and therefore it is believed that it is low correlated with stock (Baur and Lucey, 2010).

Meanwhile, the growth of global economy, increases in mass production and world trade, together with the vast usage of technology, put oil in a very special position. The fluctuation of oil price will increase and decrease market's assurance with its direct effect on production costs. According to Gencer and Demiralay (2014), there are two channels whereby the business activity level is highly influenced by oil price movements and impacts the stock price: (1) the business earnings and cash flows are directly affected by oil prices; and (2) investor's required rate of return, which is determined by inflation, risk and interest rates. With the current instability of oil price, it is now quite apt to add research on the impact of oil price towards equity return. Through various studies conducted, there were mixed results. Some studies show a positive relation, some negative and some no significant relation. Arouri and Nguyen (2010) examined the shortterm relations in the aggregate as well as sector by sector levels in Europe. The results show a robust significant relation between changes of oil price and stock market for most of the European sectors. Park and Ratti (2008) studies the oil price shocks and stock markets in US and 13 European countries with data comprised from 1986 until 2005. The findings show that real oil price has a significant impact on real sectoral indices in all countries. Degiannakis, Filis and Floros (2013) indicate that the supply side oil price shocks result in low to moderate positive correlation levels. Hosseini, Ahmad and Lai 
(2011) explores the cointegration between stock market indices and macroeconomic variables and the findings show that increase in crude oil price in China results in a positive impact, whereas in India, there is potentially a negative impact in the long-run.

A study done for South Korea reveals that the movement of oil price affects the stock market significantly (Masih, Peters and De Mello, 2011). Fatima and Bashir (2014) investigated the volatility of international oil prices and stock market of emerging markets in Asia, namely, Pakistan and China, compiling monthly data from January 1998 until December 2013. The findings for this study show that there is a low reaction in stock market due to fluctuations of oil price. Another findings argue that there is a strong indication that oil price has impact on stock price returns in emerging markets although the cointegration depends on the frequency of data used (Basher and Sadorsky, 2006). Arouri (2011) examines the responses of Europe's stock market to changes in oil price and the result shows a strong significant cointegration between both variables for most European sectors. Kalyanaraman and Tuwajri (2014) find that there is a two-way causality between stock prices and oil price and both variables have a positive cointegration. However, Khan and Zaman (2011) and Kuwornu and Victor (2011)'s findings reveal that there is no significant effect of oil price on stock market return. This could be due to the consistent rise in inflation and oil price that affects the stock price badly. Narayan and Narayan (2010)'s findings show that oil price has positive significant effect on Vietnam's stock price and index in Tehran Stock Exchange. In addition, there is also a finding showing oil price having a cointegration with the Russian Stock Market (Fedorova and Pankratov, 2010).

The idea of a strong cointegration between stock prices and exchange rates have been well liked among many people. The cointegration between both variables have also been the focus for many researchers in doing empirical analysis (Jaafar and Ismail, 2009). According to Kalyanaraman and Al Tuwajri (2014), good market approach and portfolio balance approach are the two methods in evaluating the cointegration between variables, stock prices and exchange rate. Singh (2015) mentioned that goods market approach (flow oriented) that was initially examined by Dornbusch and Fisher, hypothesized that the movement of exchange rate caused movement in stock price. On the other hand, portfolio balance approach suggests the opposite, whereby the movement in stock price can affect exchange rate.

Many researches have been done where the results are mixed (Geetha, Mohidin, Chandran and Victoria, 2011; Jaafar and Ismail, 2009). Lim and Sek (2014) conducted empirical analysis to examine the inter-cointegration between volatility of exchange rate and sectoral indices in four emerging markets in Asia, namely Korea, Indonesia, Thailand and Phillipines with sample period from January 1990 until December 2015. The result of this analysis shows that there is no long-run cointegrating cointegration between both variables. However, there is a two-way short-run cointegration between the volatility of exchange rate and sectoral indices in all four countries. A study by Wongbangpo and Sharma (2002) on 5 ASEAN countries reveals that exchange rate has a positive relation to stock prices in Indonesia, Malaysia and the Philippines, but a negative relation in Singapore and Thailand.

Mookerjee and Yu's analysis (1997) found that there is no long-run equilibrium cointegration between exchange rate and the stock prices of Singapore Stock Market. The same evidence was found from a study by Zhao (2010) that was conducted with data from China. In addition, Bekhet and Mugableh (2012)'s empirical analysis indicates that exchange rate is negatively related with Malaysian Stock Market Index and it is consistent with the mixed findings between the two variables as found in a study conducted in Malaysia (Jaafar and Ismail, 2009). However, a study conducted on the exposure of exchange rate with sectoral return volatilities 
from Japanese industrial sectors found that there were four sectors having positive exposure to changes in exchange rate, whereas two sectors had a negative exposure (Jayasinghe and Tsui, 2008).

In another study investigating the cointegration between stock market's in Malaysia, US and China, the findings show that there is longrun cointegrating cointegration between stock markets in the three countries with exchange rate. There is also evidence showing that there is a significant cointegration between exchange rate and stock market in China (Geetha, Mohidin, Chandran and Chong, 2011). Kpanie, Esumanba and Sare (2014) used quarterly data for the period of 1995 until 2011 and found evidence that exchange rate has negative cointegration with stock market performance. Khan and Zaman (2011) examined on impact of macroeconomic variables on stock prices in Karachi Stock Exchange and the results show that exchange rate positively affects stock prices.

Therefore, the aim of this paper is to provide further understanding in terms of the cointegration between sectoral indices movement in Bursa Malaysia especially from both long run and short run perspectives with the changes in macroeconomic variables namely crude oil price (OP), gold price (GP) and exchange rate (ER). It is hoped that it will be beneficial to the investors, portfolio managers, and market members as they can determine the performance and behaviors of stock price. With the forecast on market prices together with well diversified investment portfolio, it can help the investors to minimize the risks as well as increase the future return in the market.

\section{Problem Statement}

In Malaysia, stock market plays an important role in nourishing capital formation and sustaining the economic growth. It does not only comprise of gathering and transferring funds and capital, but it also shares the risks. Investors face the highest risk when investing in the stock market compared to other form of financial investment such as bond, treasury bill and fixed deposit. Stock price fluctuates almost every second and most people perceive share price movement as unpredictable, also known as "random walk". There is no benchmark for the movement of stock prices. Therefore, many studies have been conducted by different researchers about the cointegration between macroeconomic variables and market return. The problem is that, as much as the importance of stock market in economic growth has been explored, there are limited studies devoted towards the sectoral indices movement perspective (Jaafar and Ismail, 2009). Thus, this paper investigates the long run and short run cointegration between the selected macroeconomic variables, namely crude oil, gold price and exchange rate and ten sectoral indices of Bursa Malaysia which are Construction, Consumer Product, Industrial Production, Trading/Services, Technology, Finance, Properties, Plantation, Mining and Industrial.

\section{Methodology}

A total of 10 sector specific indices (Construction, Consumer Product, Industrial Production, Trading/Services, Technology, Finance, Properties, Plantation, Mining and Industrial) and 3 macroeconomic variables (gold price, crude oil price and exchange rate) were being considered in this paper. The variables data were collected on monthly frequency from January 1995 to December 2014 with a total of 240 monthly observations for each variable except for technology sector which accounted for 176 of monthly observation. The dependent variable for this study is sectoral indices at Bursa Malaysia. The macroeconomic variables are monthly frequency from January 1995 to December 2014 with a total of 240 monthly observations for each of the variables. 
The brief description of each variable used is presented in Table 1 below.

Table 1: Data description

\begin{tabular}{|l|l|l|l|}
\hline Variables & Description & Units & $\begin{array}{l}\text { Source of } \\
\text { Data }\end{array}$ \\
\hline $\begin{array}{l}\text { Sectoral } \\
\text { Indices }\end{array}$ & $\begin{array}{l}\text { Composite market } \\
\text { index in Malaysia } \\
\text { (from sector) }\end{array}$ & Index & Data stream \\
\hline $\begin{array}{l}\text { Gold } \\
\text { Price }\end{array}$ & Unit per troy ounce & USD & $\begin{array}{l}\text { World Gold } \\
\text { Council }\end{array}$ \\
\hline $\begin{array}{l}\text { Crude Oil } \\
\text { Price }\end{array}$ & $\begin{array}{l}\text { Dated Brent price per } \\
\text { barrel }\end{array}$ & USD & Worldbank \\
\hline $\begin{array}{l}\text { Exchange } \\
\text { Rate }\end{array}$ & $\begin{array}{l}\text { Value of 1 U.S. } \\
\text { Dollarin in Malaysian } \\
\text { Ringgits }\end{array}$ & RM & $\begin{array}{l}\text { International } \\
\text { Financial } \\
\text { Statistic }\end{array}$ \\
\hline
\end{tabular}

Several tests have been conducted to investigate the cointegration between macroeconomic variables with sectoral indices. The tests are presented in the following manner: Unit Root Test, Johansen Cointegration, Vector Error Correction Model (VECM) and Vector Autoregression (VAR).

\section{Empirical Findings}

The findings from the analysis indicated that all the data series are stationary. Table 2 below shows the information regarding the issues of stationary between all sectoral indices and the three identified macroeconomic variables. The stationarity of the series of data is found to be at $1 \%$ significant level for both Augmented Dickey Fuller (ADF) and Philips Perron (PP) after it has been converted into first different. In other word, all data series are in good condition to be analyzed based on the findings which have been obtained from both ADF and Philip-Perron stationarity test.

Table 2: Unit Root Test Result

\begin{tabular}{|l|c|c|c|c|}
\hline \multirow{2}{*}{ Variables } & \multicolumn{2}{|c|}{ ADF } & \multicolumn{2}{c|}{ PP } \\
\cline { 2 - 5 } & Level & 1st Diff. & Level & 1st Diff. \\
\hline $\begin{array}{l}\text { Sectoral } \\
\text { Indices }\end{array}$ & & & & \\
\hline FIN & -1.788012 & $-13.59859 * * *$ & -2.159295 & $-13.83876^{* * *}$ \\
\hline CONSTR & -2.194709 & $-12.57312^{* * *}$ & -2.207325 & $-12.61909 * * *$ \\
\hline IND & -2.059837 & $-14.84716^{* * *}$ & -2.192713 & $-14.86092 * * *$ \\
\hline
\end{tabular}

\begin{tabular}{|l|l|l|l|l|}
\hline CONSPRO & -1.46517 & $-14.60678^{* * *}$ & -1.566846 & $-14.66281^{* * *}$ \\
\hline INDPRO & -2.30984 & $-12.30046^{* * *}$ & -1.75736 & $-12.2651^{* * *}$ \\
\hline PLANT & -2.311269 & $-13.15414^{* * *}$ & -2.30096 & $-13.17597^{* * *}$ \\
\hline PROPER & -1.767163 & $-13.94071^{* * *}$ & -1.92969 & $-14.01214^{* * *}$ \\
\hline TECH & -9.077946 & $-10.8693^{* * *}$ & $-7.523257 * * *$ & $-11.42466^{* * *}$ \\
\hline TIN & -2.898853 & $-16.45741^{* * *}$ & -2.943868 & $-16.45426^{* * *}$ \\
\hline TRADE & -2.313604 & $-13.33381^{* * *}$ & -1.92658 & $-13.3018^{* * *}$ \\
\hline $\begin{array}{l}\text { Economic } \\
\text { Indicators }\end{array}$ & & & & \\
\hline GOLD & -1.696665 & $-18.41776^{* * *}$ & -1.810945 & $-18.55298^{* * *}$ \\
\hline OIL & $-3.21881^{*}$ & $-9.539614^{* * *}$ & -2.912781 & $-9.589793^{* * *}$ \\
\hline XCHNGE & -2.207027 & $-12.64244^{* * *}$ & -2.071746 & $-12.54382^{* * *}$ \\
\hline
\end{tabular}

Note: $* * * * *$ and $*$ denotes significance at $1 \%, 5 \%$ and $10 \%$ level, respectively.

In the next step, the cointegration between the stationary variables has been tested by using Johansen's Trace and Maximum Eigenvalue test. The result of these test are shown in Table 3 below. The Trace test indicates the existence of two co-integration equations at $5 \%$ level of significance and the maximum eigenvalue test makes the confirmation of this result. Based on the result, only test statistics for technology sector indices indicated at most one cointegration relationship, where we reject the null hypothesis of no cointegration at $5 \%$ level of significance. So, there is existence of a long-run relationship between the economic variables and the stock indices in technology sector. Therefore, the analysis from this study has revealed that most of the sectoral indices in Bursa Malaysia have not cointegrated in the long run with the three macroeconomic variables (gold price, oil price and exchange rate). Results in Table 3, clearly highlighted the scenario that Technology sector has been observed to have long run cointegration with economic variables (significant at 5\% level).

Table 3: Summary of long-run relationship (Johansen Co-integration test)

\begin{tabular}{|l|l|l|l|l|}
\hline \multirow{2}{*}{ Sectoral Indices } & Trace & 0.05 & $\begin{array}{l}\text { Max- } \\
\text { Eigen }\end{array}$ & 0.05 \\
\cline { 2 - 5 } & Statistic & $\begin{array}{l}\text { Critical } \\
\text { Value }\end{array}$ & Statistic & $\begin{array}{l}\text { Critical } \\
\text { Value }\end{array}$ \\
\hline FINANCIAL & $45.47817^{*}$ & 47.85613 & 25.14138 & 27.58434 \\
\hline CONSTRUCTION & 39.80648 & 47.85613 & 16.24638 & 27.58434 \\
\hline INDUSTRIAL & 40.27051 & 47.85613 & $25.44105^{*}$ & 27.58434 \\
\hline
\end{tabular}


GJAT | JUNE 2017 | VOL 7 ISSUE 1 | 24

ISSN : 2232-0474 | E-ISSN : 2232-0482

www.gjat.my

\begin{tabular}{|l|l|l|l|l|}
\hline $\begin{array}{l}\text { CONSUMER } \\
\text { PRODUCT }\end{array}$ & 39.81783 & 47.85613 & 18.73380 & 27.58434 \\
\hline $\begin{array}{l}\text { INDUSTRIAL } \\
\text { PRODUCT }\end{array}$ & 35.85933 & 47.85613 & 17.60309 & 27.58434 \\
\hline PLANTATION & 27.24875 & 47.85613 & 14.39345 & 27.58434 \\
\hline PROPERTIES & 39.89146 & 47.85613 & 19.43927 & 27.58434 \\
\hline TECHNOLOGY & $49.65300^{* *}$ & 47.85613 & $\mathbf{2 8 . 9 9 1 7 9 * *}$ & 27.58434 \\
\hline TIN \& MINING & 37.54712 & 47.85613 & 19.10296 & 27.58434 \\
\hline $\begin{array}{l}\text { TRADE \& } \\
\text { SERVICE }\end{array}$ & 33.66470 & 47.85613 & 18.91456 & 27.58434 \\
\hline
\end{tabular}

Table 5: VAR Causality Test Result

On the other hand, the finding regarding the short-run relationship between sectoral indices and all identified macroeconomic variables had been gathered through the application of the VAR/VECM causality test. Based on the Johansen cointegration test, the analysis found that the variables are not cointegrated in the long run except for technology sector. So, for technology, we employ VECM test (refer to Table 4) while for the others, we employ VAR test (refer to Table 5).

Table 4: VECM Causality Test Result

\begin{tabular}{|c|c|c|c|c|}
\hline \multirow{3}{*}{ 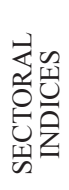 } & \multicolumn{3}{|c|}{ ECONOMIC INDICATORS } & \multirow{2}{*}{$\begin{array}{l}\text { LONG } \\
\text { RUN }\end{array}$} \\
\hline & \multicolumn{3}{|c|}{ SHORT RUN } & \\
\hline & $\begin{array}{l}\text { GOLD } \\
\text { PRICE }\end{array}$ & $\begin{array}{c}\text { OIL } \\
\text { PRICE }\end{array}$ & $\begin{array}{l}\text { EXCHANGE } \\
\text { RATE }\end{array}$ & ECT \\
\hline \multirow{2}{*}{ 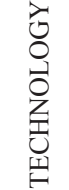 } & 1.844551 & 0.696577 & 1.60605 & -0.181389 \\
\hline & [0.3976] & [0.7059] & [0.448] & {$[0.0000]^{* * *}$} \\
\hline
\end{tabular}

Result from the VECM for technology sector shows that in the short run, none of the economic variables has significant impact to the sector indices. However in the long-run, it suggests that the technology sector indices and the economic variables have long-run relationship. For other sectors' indices, VAR Causality test has been applied and the findings indicate that they are not cointegrated in the long run.

\begin{tabular}{|l|c|c|c|}
\hline \multirow{2}{*}{ Sectoral Indices } & \multicolumn{3}{|c|}{ ECONOMIC INDICATORS } \\
\cline { 2 - 4 } & $\begin{array}{c}\text { GOLD } \\
\text { PRICE }\end{array}$ & $\begin{array}{c}\text { OIL } \\
\text { PRICE }\end{array}$ & $\begin{array}{c}\text { EXCHANGE } \\
\text { RATE }\end{array}$ \\
\hline \multirow{2}{*}{ FINANCIAL } & 9.569275 & 1.779232 & 14.32599 \\
\cline { 2 - 4 } & {$[0.0084]^{* * *}$} & {$[0.4108]$} & {$[0.0008]^{* * *}$} \\
\hline \multirow{2}{*}{ CONSTRUCTION } & 4.807309 & 2.096949 & 3.418332 \\
\cline { 2 - 4 } & {$[0.0904]^{*}$} & {$[0.3505]$} & {$[0.181]$} \\
\hline \multirow{2}{*}{ INDUSTRIAL } & 2.998881 & 1.146201 & 11.39033 \\
\cline { 2 - 4 } & {$[0.2233]$} & {$[0.5638]$} & {$[0.0034]^{* * *}$} \\
\hline \multirow{2}{*}{$\begin{array}{l}\text { CONSUMER } \\
\text { PRODUCT }\end{array}$} & 18.89343 & 3.052934 & 4.306954 \\
\cline { 2 - 4 } $\begin{array}{l}\text { INDUSTRIAL } \\
\text { PRODUCT }\end{array}$ & {$[0.0001]^{* * *}$} & {$[0.2173]$} & {$[0.1161]$} \\
\cline { 2 - 4 } & 9.350823 & 1.921824 & 2.775284 \\
\hline \multirow{2}{*}{ PLANTATION } & $7.0093]^{* * *}$ & {$[0.3825]$} & {$[0.2497]$} \\
\cline { 2 - 4 } & {$[0.024]^{* *}$} & 2.815782 & 7.884758 \\
\hline \multirow{2}{*}{ PROPERTIES } & 2.153648 & 2.622194 & {$[0.0194]^{* *}$} \\
\cline { 2 - 4 } & {$[0.3407]$} & {$[0.2695]$} & {$[0.0015]^{* * *}$} \\
\hline \multirow{2}{*}{ TIN \& MINING } & 3.257468 & 2.334054 & 6.25617 \\
\cline { 2 - 4 } & {$[0.1962]$} & {$[0.3113]$} & {$[0.0438]^{* *}$} \\
\hline \multirow{2}{*}{$\begin{array}{l}\text { TRADE \& } \\
\text { SERVICE }\end{array}$} & 15.21668 & 3.651159 & 7.338608 \\
\cline { 2 - 4 } & {$[0.0005]^{* * *}$} & {$[0.1611]$} & {$[0.0255]^{* *}$} \\
\hline
\end{tabular}

Note: $* * * * *$ and $*$ denotes significance at $1 \%, 5 \%$ and $10 \%$ level, respectively.

Table 5 above shows that gold price and exchange rate appear to have significant cause towards sectoral indices for financial sectors. It indicates that any movement in gold price and exchange rate will give impact to financial sector indices in the short run. This result is similarly found in the sector of plantation and trade \& service. In construction sector, none of the variables is found to have significant cause towards sectoral indices. It means that the movement of gold price, oil price or exchange rate will not give impact to the constructions sectoral indices in the short-run. For the sector of industrial, properties and tin \& mining, the changes in exchange rate has also found to be cointegrated together with the sectoral indices. However for the other two variables, gold price and oil price, none of them have significant cause towards these sectoral indices. Meanwhile, the VAR results indicate that only gold price has significant impact towards indices for the sector of consumer product and industrial product. Oil price and exchange rate appears to have no significant impact on these two sectors. This 
result is similar to the findings by Saeed (2012) who found that exchange rate and oil prices do not share a short-run causality relationship with the returns from any sectors. In the meantime, Saeed (2012) assumed that exchange rate and oil prices affect only specific sectors like oil and gas sector, automobile, cable and electronics. In terms of economic variables, this analysis found that exchange rate and gold price appear to have significant impact on sectoral indices in many sectors. The influences of exchange rate towards stock indices movement have been found in many previous researches such as Jamil and Ullah (2013). Similarly, gold price is also found to be a significant contributor towards market indices in previous studies, such as Baur and McDermott (2009). Meanwhile, none of the sector is found to be significantly caused by oil price. It means that oil price is not a significant contributor towards the performance of all sectoral indices in the short-run.

As referred to the overall explanation above, it could be confirmed that there are similarities as well as differences in terms of the cointegration between the movements of the three macroeconomic variables, namely gold price, oil price, exchange rate and the changes in sectoral indices.

\section{Conclusion}

This paper has examined the cointegration between the movements of sectoral indices of the stock market and selected macroeconomic variables by applying time series analysis. Both short-run and long-run cointegration between sectoral indices and macroeconomic variables are analyzed. This paper ascertained the fact that in both long run and short run, there is a linkage between the selected macroeconomics variables and sectoral indices in Bursa Malaysia. It suggests that the technology sector indices and the economic variables have long-run cointegration. In the short run, it indicates that any movement in gold price and exchange rate will give impact to financial sector indices as well as plantation and trade $\&$ services. In the construction sector, none of the variables is found to have significant cause towards sectoral indices. The finding from this analysis is considered important in providing information to the investors, especially for those who are interested in diversifying their investment in various sectors towards establishing well diversified portfolio of investment.

\section{Acknowledgement}

I would like to thank Nurulhuda ibrahim, Nur Zawani Johari and Yong Athirah Mohd Aznam, MBA students Arshad Ayub Graduate Business School, Universiti Teknologi MARA for their kind contribution in the preparation of the manuscript.

\section{References}

Arouri, M. E. H. (2011). Does crude oil move stock markets in Europe? A sector investigation. Economic Modelling, 28(4), 1716-1725.

Arouri, M. E. H., \& Nguyen, D. K. (2010). Oil prices, stock markets and portfolio investment: evidence from sector analysis in Europe over the last decade. Energy Policy, 38(8), 4528-4539.

Basher, S. A., \& Sadorsky, P. (2006). Oil price risk and emerging stock markets. Global Finance Journal, 17(2), 224-251.

Baur, D. G., \& Lucey, B. M. (2010). Is gold a hedge or a safe haven? An analysis of stocks, bonds and gold. Financial Review, 45(2), 217229.

Baur, D. \& McDermott, K. (2010). "Is Gold a Safe Haven? International Evidence". Journal of Banking and Finance, 4, 1886-1898.

Bekhet, H. A., \& Mugableh, M. I. (2012). Investigating equilibrium cointegration between macroeconomic variables and Malaysian stock market index through bounds tests approach. International Journal of Economics and Finance, $4(10), 69-81$. 
Degiannakis, S., Filis, G., \& Floros, C. (2013). Oil and sectoral indices: Evidence from European industrial sector indices in a timevarying environment. Journal of International Financial Markets, Institutions and Money, 26, 175-191.

Dempster, N. and Artigas, J. C. (2010). Gold: Inflation hedge and long-term strategic asset. Journal of Wealth Management, 13(2), 69-75.

Fatima, T., \& Bashir, A. (2014). Oil Price and Stock Market Fluctuations: Emerging Markets (A Comparative Study of Pakistan and China). International Review of Management and Business Research, 3(4), 1958-1976.

Fedorova, E. A., \& Pankratov, K. A. (2010). Influence of macroeconomic factors on the Russian stock market. Studies on Russian Economic Development, 21(2), 165-168.

Geetha, C., Mohidin, R., Chandran, V. V., \& Chong, V. (2011). The cointegration between inflation and stock market: evidence from Malaysia, United States and China. International journal of economics and management sciences, $1(2), 1-16$.

Gencer, H. G., \& Demiralay, S. (2014). Shock and Volatility Spillovers between Oil Prices and Turkish Sector Returns. International Journal of Economics and Finance, 6(2), 174-180.

Hosseini, S. M., Ahmad, Z., \& Lai, Y. W. (2011). The role of macroeconomic variables on stock market index in China and India. International Journal of Economics and Finance, 3(6), 233243.

Jaafar, P., \& Ismail, A. (2009). Dynamic relationship between sector-specific indices and macroeconomic fundamentals, Malaysian Accounting Review, 8(1), 81-100.

Jamil, M. \& Ullah, N. (2013). Impact of Foreign Exchange rate on stock prices, Foundation University Institute of Engineering
\& management Sciences, Journal of Business and Management, 7(3), 45-51.

Jayasinghe, P., \& Tsui, A. K. (2008). Exchange rate exposure of sectoral returns and volatilities: Evidence from Japanese industrial sectors. Japan and the World Economy, 20(4), 639-660.

Joshi, P., \&Giri, A. K. (2013). An empirical analysis of the cointegration between stock market indices and macro-economic variables: Evidences from India. International Academic Research Journal of Economics and Finance, 2(1), 17-24.

Kalyanaraman, L., \& Al Tuwajri, B. (2014). Macroeconomic forces and stock prices: some empirical evidence from Saudi Arabia. International Journal of Financial Research, $5(1), 81$.

Khan, M. N., \& Zaman, S. (2011). Impact of Macroeconomic Variables on Stock Prices: Empirical Evidence from Karachi Stock Exchange, Pakistan. International Journal of Operational Management, Marketing and Services, 1(1), 78-84.

Kpanie, A. F., \& Esumanba, S. V. (2014). Cointegration between stock market performance and macroeconomic variables in Ghana, 46-53.

Lim, S. Y., \& Sek, S. K. (2014). Exploring the Inter-cointegration between the Volatilities of Exchange Rate and Sectoral indices. Procedia Economics and Finance, 14, 367-376.

Masih, R., Peters, S., \& De Mello, L. (2011). Oil price volatility and stock price fluctuations in an emerging market: evidence from South Korea. Energy Economics, 33(5), 975-986.

Mohamed, S., Ali, A., Azman, K. \& Abdullah, N. (2011). Malaysian Sectoral Indices VS Macroeconomic Factors, Any Correlation?: Evidence From Malaysia, 493-497.

Mookerjee, R., \& Yu, Q. (1997). Macroeconomic 
variables and stock prices in a small open economy: The case of Singapore. Pacific-Basin Finance Journal, 5(3), 377-388.

Narayan, P. K., \& Narayan, S. (2010). Modelling the impact of oil prices on Vietnam's stock prices. Applied Energy, 87(1), 356-361.

Park, J., \& Ratti, R. A. (2008). Oil price shocks and stock markets in the US and 13 European countries. Energy Economics, 30(5), 25872608.

Rahman, A. A., Sidek, N. Z. M., \&Tafri, F. H. (2009). Macroeconomic determinants of Malaysian stock market. African Journal of Business Management, 3(3), 95-106.

Saeed, S. (2012). Macroeconomic Factors and Sectoral Indices: A Study of Karachi Stock Exchange (Pakistan). European Journal of Business and Management, 4(17), 132-15

Singh, G. (2015). The Cointegration Between Exchange Rate and Stock Price in India: An Empirical Study. IUP Journal of Financial Risk Management, 12(2), 18-29.

Sujit, K. S., \& Kumar, B. R. (2011). Study on dynamic cointegration among gold price, oil price, exchange rate and stock market returns. International Journal of Applied Business and Economic Research, 9(2), 145-165.

Wongbangpo, P., \& Sharma, S. C. (2002). Stock market and macroeconomic fundamental dynamic interactions: ASEAN-5 countries. Journal of Asian Economics, 13(1), 27-51.

Zhao, H. (2010). Dynamic cointegration between exchange rate and stock price: Evidence from China. Research in International Business and Finance, 24(2), 103-112. 